\title{
Secure Controlling System for Cross Layer Reliability for Ultra Huge Scale Framework
}

\author{
S. Theivasigamani, D. Jeyapriya, G. Michael
}

\begin{abstract}
Ultra wideband $(\mathrm{UWB})$ radio ascends as an attractive physical layer for extraordinarily chosen frame (MANET) adaptability. Guiding in MANET is a study that can be inferred from the vibrant thinking of the topology system and the impediments to resources. In this document, $U W B$ is proposing a stable coordination structure concentrating on the flimsiness problem from the foggy area of communication. This tool is a cross-layer shift of tradition-controlled uncommonly delegated on-ask for vector (AODV), called CLS AODV. The managing exposure calculation is associated by showing source planning and extraordinarily chose on-request multipath remove vector $(A O M D V)$ organizing. Rather than the open way in AODV, the got sign quality can be used to reveal shady territory wish affiliation state data, just as course state seeing. A preventive neighborhood fix course gauge dependent on HELLO knows about keeping the affiliation breakage event. Greetings notification is extended not only for neighborhood identification and exchange of neighborhood data, but also as an ON / OFF fee for controlling neighborhood location layout and HELLO design. The proliferation shows the progression of $C L S A O D V$ to the extent of the package incident and the typical end-to-end acknowledgement without exchanging the differentiated performance.
\end{abstract}

Keywords : Controlling system, reliability, Ultra wideband

\section{INTRODUCTION}

Ultra wideband (UWB) radio ascends as an attractive physical layer for extraordinarily chosen frame (MANET) adaptability. Guiding in MANET is a study that can be inferred from the vibrant thinking of the topology system and the impediments to resources. In this document, UWB is proposing a stable coordination structure concentrating on the flimsiness problem from the foggy area of communication. This tool is a cross-layer shift of tradition-controlled uncommonly delegated on-ask for vector (AODV), called CLS AODV [1-5]. The managing exposure calculation is associated by showing source planning and extraordinarily chose on-request multipath remove vector (AOMDV) organizing. Rather than the open way in AODV, the got sign quality can be used to reveal shady territory wish affiliation state data, just as course state seeing. A preventive neighborhood fix course gauge dependent on HELLO knows about keeping the affiliation breakage event. Greetings

Revised Manuscript Received on July 22, 2019.

S. Theivasigamani *, Department of CSE, Bharath Institute of Higher Education and Research, Chennai, Tamilnadu, India.

D. Jeyapriya, Department of CSE, Bharath Institute of Higher Education and Research, Chennai, Tamilnadu, India.

G. Michael, Department of CSE, Bharath Institute of Higher Education and Research, Chennai, Tamilnadu, India. notification is extended not only for neighborhood identification and exchange of neighborhood data, but also as an ON / OFF fee for controlling neighborhood location layout and HELLO design. The proliferation shows the progression of CLS AODV to the extent of the package incident and the typical end-to-end acknowledgement without exchanging the differentiated performance [6-11].

\section{UNIQUE}

Our work's motivation is derived from the dim region of communication problem. In this region, a core in its coordinating board could have a real blue course, yet the magnitude of the package setback is large [12]. The association between the center point and its next bounce in obscurity locale of correspondence is shaky, which will adversely affect the efficiency of the entire course. The rule clarification behind dim land occasion resides in how highly phenomenal is the operation for transmitting control signals and unicast information packages. Coordinating control posts may send / get the opportunity to show the accessibility of the neighbour while no information sets reach the associated ricochet $[13,14]$. To be precise, telecom is performed at a fundamental piece rate on an ongoing basis while data packets are sent at greater prices on a regular basis. Transmissions at reduced piece rates are more stable and more removable than at greater prices can be achieved. In addition, there is no insistence on conveying message, which does not ensure bidirectional membership. The convey message's smaller parcel size also provides greater strength against block and collision compared to unicast[15-18].

AODV depends on uneven neighbor recognition HELLO text. It contributes to the letter of turbid land, underlined in the AODV-UU readme record by means of certifiable tests. Besides, convey messages furthermore encounter the evil impacts of col-lisions and obstructs.

Since foggy region correspondence totals in a specific geographic zone, place information can overhaul execution coordination completely. Two or three region based planning customs have been conveyed for astoundingly named structures. For instance, the covetous edge stateless whipping ing (GPSR) is a position-based directing instrument which has been appeared to beat different other organizing conventions. Framework is proposed to misuse an area data in course disclosure, bundle hand-off, and course reinforce, which makes courses even more reliable and savage to focus point flexibility. Zone Bolstered Controlling (LAR) limits the journey for another course as per zone information to a lower' Request Zone,' bringing about a colossal decline in overhead victory[8]. Directing data from 
the geographic area with help needs each core point to be equipped with an general arrangement scheme (GPS) in the previously mentioned explorations. There are, however, different conditions in which GPS is not powerful, UWB based on inspiration can interlace the right position-territory (in centimeter supply) with the corresponding low-data level $[19,20]$.

Differentiated and GPS-helped structure using satellite, UWB contraptions execute position territory without any other person.

\section{RESPONSIBILITIES}

Following a cross-layer arrangement strategy, the coordinating section submitted uses low-layer data to implement adaptable guidance frameworks by acknowledging and anticipating the opportunity for correspondence to decrease areas, i.e. shaky associations. The low-layer data in this insinuates has been given neighborhood hail value, region data and data, the combination of which can efficiently represent associated state and topological data.

Our quality-based coordination segment called CLS AODV, including, of course, three essential elements: (1) coherent disclosure. By displaying dim zone avoidance, the AOMDV disclosure estimate of distinctive categories is extended. In addition, an enlisting model is laid up to select the most stable route relative to the shortest path. (2) course checking. Amidst the course reinforce process, the probability of the event of shady area is figured in light of the got hail attributes utilizing an exact framework, and (3) preemptive course fix. There is damage to the progressing HELLO story in AODV. As a qualification in the underlying HELLO check, the HELLO signal is expanded not only for neighborhood identification and exchange of neighborhood data, but also as an ON / OFF application for command of neighborhood cluster points location layout and HELLO design. The section CLS AODV is acknowledged and transferred to the organizationNS-2. Entertainment shows that CLS AODV is giving AODV a lot of highest performance [21-23].

\section{STABLE COURSE DISCLOSURE}

In AODV, when a source center point has to ship a parcel to the target, it first scans its course chart to determine if it is unlikely to start an genuine path towards the target. If it does not occur, the source cluster point starts a method of transparency of the course by flooding through the structure a Route Request (RREQ) file. As determined in fragment 2, the delivery of texts has a few remarkable characteristics that distinguish them from information packages. Despite the possibility of hearing RREQ emails, the same may not be significant for exchanging information packs between two facilities, adding to shaky inverse links. In the context of source coordination and AOMDV, we suggest an improved stable route collection structure to explore various paths between origin and goal in a single course disclosure. For course choice, a soundness-based coordination metric is also shown [24, 25].

\section{RESULTS AND DISCUSSION}

Much equivalent to the AOMDV controlling convention, we imply planning up-dates acquired by strategies for RREQs or RREPs as 'course progressions'. In AOMDV, recalling a definitive target to keep up various courses for a relative succession number, each inside keeps up a variable called stopped weave mean every goal, which tends to the most preposterous jump The convention just permits bearing the support ways to deal with keep running with chop down ricochet check. Notwithstanding how it is basic to ensure circle opportunity, the course attestation run unequivocally restricts the measure of different courses. With a specific extreme target to collect increasingly certified courses, course divulgence procedure is pushed ahead [26].

In our broadening, RREQ wrap keeps up the entire course data from source to objective. Source vanquishing is utilized just in different courses revelation. Area of the course outline is equivalent to AOMDV. Two primary approaches are utilized to interface the sum and span of candidate classes for the huge measure of classes possibly found. One is to gather disjoint interface classes as in AOMDV, which considers the likelihood of related and simultaneous bafflement of spread classes. Previous shows up, on the opposite side, have demonstrated that a controlling convention that gives unbelievable power may should be traded on throughput [27, 28]. The course will either end with the most restricted way with longer (contingent upon delicate) associations or stable course (littler relationship) with longer term. Amidst the course presentation technique, foggy district recognizing evidence is finished in any case, which guarantees the yielded partners with be determined inside the not so distant future. All things considered, in smaller structures, courses made out of more affiliations will probably encounter the malicious effects of debasement in course unwavering quality. We show a parameter called' Tolerance Hop' to keep up a primary good ways from superfluous long strategies when thinking about this wastefulness. A course' Tolerance Hop' will be perceived by the objective longer than one formally stopped. RREP tempest can be talked about in like manner as course disclosure is counteracted all through the whole structure. Note that the RREQ signal is spoken with D flag set, demonstrating that this RREQ may be responded to by a restrictive target center [29, 30].

\section{CONCLUSION}

In this document, a coordinating section centered on trustworthiness is suggested to tackle the problem of cloudy land correspondence, which is an AODV cross-layer revision. The philosophies obviously presentation for AOMDV and source coordination are consolidated and improved with a definitive objective of gathering various techniques. A figuring model is set up to make planning estimations for path affirmation regarding course unwavering quality, which has been pragmatic by the redirection works out as expected. By the day's end, if the properties of a remote pennant can be recouped, the data that has gone past the information being transmitted ought to be circulated air through and refrigerated, which has come about in past 
assessments being viable.

\section{REFERENCES}

1. Gowri Sankaran, B., Karthik, B. \& Vijayaragavan, S.P. 2019, "Weight ward change region plummeting change for square based image huffman coding", International Journal of Innovative Technology and Exploring Engineering, vol. 8, no. 10, pp. 4313-4316.

2. Gowri Sankaran, B., Karthik, B. \& Vijayaragavan, S.P. 2019, "Image compression utilizing wavelet transform", International Journal of Innovative Technology and Exploring Engineering, vol. 8, no. 10, pp. 4305-4308.

3. Kandavel, N. \& Kumaravel, A. 2019, "Offloading computation for efficient energy in mobile cloud computing", International Journal of Innovative Technology and Exploring Engineering, vol. 8, no. 10, pp. 4317-4320.

4. Vinoth, V.V. \& Kanniga, E. 2019, "Reversible data hiding in encrypting images-an system", International Journal of Engineering and Advanced Technology, vol. 8, no. 6, pp. 3051-3053.

5. Selvapriya, B. \& Raghu, B. 2019, "Pseudocoloring of medical images: A research", International Journal of Engineering and Advanced Technology, vol. 8, no. 6, pp. 3712-3716.

6. Senthil Kumar, K. \& Muthukumaravel, A. 2019, "Bi-objective constraint and hybrid optimizer for the test case prioritization", International Journal of Engineering and Advanced Technology, vol. 8, no. 6, pp. 3436-3448.

7. Kavitha, G., Priya, N., Anuradha, C. \& Pothumani, S. 2019 "Read-write, peer-to-peer algorithms for the location-identity split", International Journal of Innovative Technology and Exploring Engineering, vol. 8, no. 9 Special Issue 3, pp. 445-447.

8. Kaliyamurthie, K.P., Michael, G., Anuratha, C. \& Sundaraj, B. 2019 "Certain improvements in alzheimer disease classification using novel fuzzy c means clustering for image segmentation", International Journal of Innovative Technology and Exploring Engineering, vol. 8, no. 9 Special Issue 3, pp. 599-604.

9. Kaliyamurthie, K.P., Sundarraj, B., Geo, A.V.A. \& Michael, G. 2019 "RIB: Analysis of I/O automata", International Journal of Innovative Technology and Exploring Engineering, vol. 8, no. 9 Special Issue 3, pp. 1019-1022.

10. Velvizhi, R., Rajabhushanam, C. \& Vidhya, S.R.S. 2019, "Opinion mining for travel route recommendation using Social Media Networks (Twitter)", International Journal of Innovative Technology and Exploring Engineering, vol. 8, no. 9 Special Issue 3, pp. 508-512.

11. Kavitha, R., Sangeetha, S. \& Varghese, A.G. 2019, "Human activity patterns in big data for healthcare applications", International Journal of Innovative Technology and Exploring Engineering, vol. 8, no. 9 Special Issue 3, pp. 1101-1103.

12. Pothumani, S., Anandam, A.K., Sharma, N. \& Franklin, S. 2019, "Extended VEOT framework - Implemented in a smart boutique", International Journal of Innovative Technology and Exploring Engineering, vol. 8, no. 9 Special Issue 3, pp. 762-767.

13. Kaliyamurthie, K.P., Michael, G., Krishnan, R.M.V. \& Sundarraj, B. 2019, "Pseudorandom techniques for the internet", International Journal of Innovative Technology and Exploring Engineering, vol. 8, no. 9 Special Issue 3, pp. 915-918.

14. Aravindasamy, R., Jeffrin Rajan, M., Rama, A. \& Kavitha, P. 2019 , "Deep learning provisions in the matlab: Focus on CNN facility", International Journal of Innovative Technology and Exploring Engineering, vol. 8, no. 9 Special Issue 3, pp. 990-994

15. Theivasigamani, S., Linda, M. \& Amudha, S. 2019, "Object sensing and its identification \& motion sensing", International Journal of Innovative Technology and Exploring Engineering, vol. 8, no. 9 Special Issue 3, pp. 545-549.

16. Mary Linda, I., Vimala, D. \& Shanmuga Priya, K. 2019, "A methodology for the emulation of IPv4", International Journal of Innovative Technology and Exploring Engineering, vol. 8, no. 9 Special Issue 3, pp. 848-852.

17. Velvizhi, R., Priya, D.J., Vimala, D. \& Linda, I.M. 2019, "Increased routing algorithm for mobile adhoc networks", International Journal of Innovative Technology and Exploring Engineering, vol. 8, no. 9 Special Issue 3, pp. 1606-1608.

18. Sangeetha, S., Anuradha, C. \& Priya, N. 2019, "DNS in real world", International Journal of Innovative Technology and Exploring Engineering, vol. 8, no. 9 Special Issue 3, pp. 937-940.

19. Geetha, C., Vimala, D. \& Priya, K.S. 2019, "Constructing multi-processors and spreadsheets with SKIVE", International Journal of Innovative Technology and Exploring Engineering, vol. 8, no. 9 Special Issue 3, pp. 516-519.

20. Yugendhar, K., Sugumar, V. \& Kavitha, P. 2019, "A novel method of univac using fuzzy logic", International Journal of Innovative Technology and Exploring Engineering, vol. 8, no. 9 Special Issue 3, pp. 435-437.

21. Kaliyamurthie, K.P., Michael, G., Elankavi, R. \& Jijo, S.A. 2019, "Implementing aggregate-key for sharing data in cloud environment using cryptographic encryption", International Journal of Innovative Technology and Exploring Engineering, vol. 8, no. 9 Special Issue 3, pp. 957-959.

22. Jeffrin Rajan, M., Aravindasamy, R., Kavitha, P. \& Rama, A. 2019, "A novel method of object orientation variation in $\mathrm{C}++$ and java", International Journal of Innovative Technology and Exploring Engineering, vol. 8, no. 9 Special Issue 3, pp. 708-710.

23. Nayak, R., Dinesh, S. \& Thirunavukkarasu, S. 2019, "A novel method improvement of rapid miner for the data mining applications", International Journal of Innovative Technology and Exploring Engineering, vol. 8, no. 9 Special Issue 3, pp. 457-460.

24. Sivaraman, K., Krishnan, R.M.V., Sundarraj, B. \& Sri Gowthem, S. 2019, "Network failure detection and diagnosis by analyzing syslog and SNS data: Applying big data analysis to network operations", International Journal of Innovative Technology and Exploring Engineering, vol. 8, no. 9 Special Issue 3, pp. 883-887.

25. Vimala, D., Linda, I.M. \& Priya, K.S. 2019, "Decoupling online algorithms from erasure coding in DNS", International Journal of Innovative Technology and Exploring Engineering, vol. 8, no. 9 Special Issue 3, pp. 950-953.

26. Rama, A., Kumaravel, A. \& Nalini, C. 2019, "Preprocessing medical images for classification using deep learning techniques", International Journal of Innovative Technology and Exploring Engineering, vol. 8, no. 9 Special Issue 3, pp. 711-716.

27. Sangeetha, S., Srividhya, S.R., Anita Davamani, K. \& Amudha, S. 2019 , "A procedure for avoid overrun error in universal synchronous asynchronous receiver transmitter (usart) by utilizing dummy join and interrupt latency method", International Journal of Innovative Technology and Exploring Engineering, vol. 8, no. 9 Special Issue 3, pp. 657-660.

28. Aravindasamy, R., Jeyapriya, D., Sundarajan, B. \& Sangeetha, S. 2019 "Data duplication in cloud for optimal performance and security", International Journal of Innovative Technology and Exploring Engineering, vol. 8, no. 9 Special Issue 3, pp. 1156-1158.

29. Aravindasamy, R., Jeffrin Rajan, M., Sugumar, V. \& Kavitha, P. 2019, "A novel method on developing superblocks and the transistor using apodryal", International Journal of Innovative Technology and Exploring Engineering, vol. 8, no. 9 Special Issue 3, pp. 982-985.

30. Sasikumar, C.S. \& Kumaravel, A. 2019, "E-learning attributes selection through rough set theory and data mining", International Journal of Innovative Technology and Exploring Engineering, vol. 8, no. 10, pp. 3920-3924

\section{AUTHORS PROFILE}

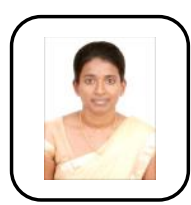

S. Theivasigamani, Assistant Professor, Department of Computer Science \& Engineering, Bharath Institute of Higher Education and Research, Chennai, India

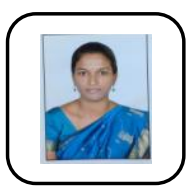

D. Jeyapriya, Assistant Professor, Department of Computer Science \& Engineering, Bharath Institute of Higher Education and Research, Chennai, India

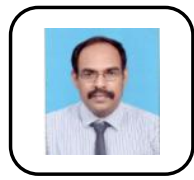

G. Michael, Associate Professor, Department of Computer Science \& Engineering, Bharath Institute of Higher Education and Research, Chennai, India 